\title{
Isolation and Structural Elucidation of Allantoin a Bioactive Compound from Cleome viscosa L.: A Combined Experimental and Computational Investigation
}

\author{
Lakshmanan G', Sivaraj $C^{2}$, Ammar A, ${ }^{3, *}$ Anantha Krishnan $D^{4}$, Gopinath $\mathrm{S}^{5}$, Saravanan $\mathrm{K}^{6}$, Gunasekaran $\mathrm{K}^{4}$, \\ Murugesan $\mathrm{K}^{7}$
}

Lakshmanan G', Sivaraj

$\mathrm{C}^{2}$, Ammar A,**, Anantha

Krishnan $D^{4}$, Gopinath $S^{5}$,

Saravanan $\mathrm{K}^{6}$, Gunasekaran

$\mathrm{K}^{4}$, Murugesan $\mathrm{K}^{7}$

'CAS in Botany, University of Madras, Guindy Campus, Chennai - 600025, INDIA. ${ }^{2}$ ARMATS Biotek Training and Research Institute, Guindy, Chennai - 600032, INDIA.

${ }^{3}$ Food science department, College of Agriculture, University of Basrah, 61004,

IRAQ.

${ }^{4}$ CAS in Crystallography and Biophysics, University of Madras, Guindy Campus,

Chennai - 600025, INDIA.

${ }^{5}$ Department of Physics, RKM Vivekananda College (Autonomous), Mylapore, Chennai - 600004, INDIA.

${ }^{6}$ Department of Physics, Periyar University, Salem - 636011, INDIA.

7SRM - Institute of Science \& Technology,

Ramapuram Campus, Chennai - 600089, INDIA.

\section{Correspondence}

\section{Dr. Ammar Altemimi}

Food science department, College of Agriculture, University of Basrah, 61004, IRAO.

E-mail: ammaragr@siu.edu; altemimiammar@yahoo.com

History

- Submission Date: 29-07-2019;

- Review completed: 23-08-2019;

- Accepted Date: 07-09-2019.

\section{DOI : 10.5530/pj.2019.11.215}

Article Available online http://www.phcogj.com/v11/i6s

\section{Copyright}

(C) 2019 Phcogj.Com. This is an openaccess article distributed under the terms of the Creative Commons Attribution 4.0 International license.

\begin{abstract}
Allantoin, a crystalline compound was isolated from the methanolic extract of Cleome viscosa and it was reported for first time from this plant. The structure of Allantoin was elucidated by single crystal XRD and it was further confirmed through FTIR and ESI-MS spectroscopy techniques. It was crystallized in monoclinic crystal system with the space group P2i/c. Electronic structure characterization of the isolated Allantoin was done through density functional theory calculation. The atomic charges, dipole moment, frontier molecular orbital and the electrostatic potential map of the molecule in the gaseous phase and in the active site have also been analyzed. The optimized geometry was used for molecular docking to identify the possible binding mode. Furthermore, the in vitro antibacterial activity of the isolated Allantoin against Gram-positive and Gram-negative bacteria was evaluated. Maximum Inhibitory Concentrations (MIC) of isolated Allantoin results showed $4 \mu \mathrm{g} / \mathrm{mL}$ for $B$. subtilis and $8 \mu \mathrm{g} / \mathrm{mL}$ for S. aureus, E. coli and K. pneumoniae.

Key words: Cleome viscosa, Allantoin, XRD, Antibacterial activity, Molecular docking.

Highlights

1. Isolation of Allantoin was reported for the first time from the methanolic extract of Cleome viscosa.

2. This is the first time in India to use methanol as the solvent for the isolation of Allantoin from this plant.

3. Allantoin exhibited significant antibacterial activity against pathogenic bacteria.

4. Molecular docking also supported the antibacterial activity of Allantoin.

5. Crystal structure determination of the compound Allantoin showed a supramolecular graphset ring motif.
\end{abstract}

\section{INTRODUCTION}

Natural products of plant origin were in high demand for curing many diseases of human beings; besides, they are biodegradable, accessible and there was no side effects on human beings. ${ }^{1,2}$ Cleome viscosa L. (Cleomaceae formerly Capparidaceae) commonly known as "wild or dog mustard," is one such herb found all over the plains of India and throughout the tropics of the World. ${ }^{3,4}$ It is an annual waste land weed with yellow flowers with sticky in nature and strong penetrating odour. In Indian traditional medicine, found throughout the greater part of roadsides, refuse heaps, waste grounds and agricultural land and waste places ${ }^{5,6}$ the seeds are small, dark brown or black and granular, possessing rubefacient, vesicant and anthelminthic properties. The seeds are occasionally used as a condiment in curries. $^{7,8}$

Previous phytochemical investigations of C. viscosa have yielded a flavonol ${ }^{9}$, dipyridodiazepinone derivative ${ }^{10}$, quercetin 3-O-P-d-glucopyranoside 7-O-a-1- rhamnopyranoside ${ }^{11,12}$, quercetin 7-O-al-rhamnopyranoside ${ }^{13}$, astragalin ${ }^{14}$, isorhamnetin
3-O-b-D-glucopyranoside ${ }^{15}$, and lactam derivative ${ }^{16}$ which possessed anticancer properties.

In this study, the crystal compound of Allantoin (imidazolidine-type) was isolated from the methanolic extract of $C$. viscosa for first time was reported. Allantoin has been found to have several pharmacological activities viz: antipsoriasis and immunostimulant, it is widely employed in dermatology, stimulation of cell mitosis, analgesic and as an anti-inflammatory agent. ${ }^{17}$ Allantoin also found in Garcinia nervosa ${ }^{18}$ comfrey plant ${ }^{19}$ green te $\mathrm{a}^{20}$ and abundant in Dioscorea spp. ${ }^{21}$ Moreover, the U.S Food and Drug Administration (FDA) disclosed as Allantoin is very safe for the development of skin care pharmaceutical products. ${ }^{22}$

An attempt has been made to understand the reason for antibacterial property of C. viscosa from both experimental and computational studies. The imidazolidine type Allantoin, a bioactive compound was isolated as a crystalline compound. To the best of our knowledge, this is the first time the Allantoin is isolated from C. viscosa. In addition to this, the isolated Allantoin was crystallized and characterized 
by single crystal XRD, FTIR and ESI-MS spectroscopy techniques. The antibacterial activity of Allantoin was evaluated against Gram-positive and Gram-negative bacteria such as Bacillus subtilis (B. subtilis), Staphylococcus aureus (S. aureus), Escherichia coli (E. coli) and Klebsiella pneumoniae (K. pneumoniae). DFT calculations were performed to understand the structure of Allantoin while molecular docking analysis was done to understand how Allantoin binds into the protein. This shed light on the nature of interactions exist between the Allantoin and proteins. Overall, this study provides useful information about Allantoin and its antibacterial properties. Besides, interactions of this compound with bacterial proteins were analyzed by in silico studies.

\section{MATERIALS AND METHODS}

\section{General experimental procedures}

TLC plates of about $0.25 \mathrm{~mm}$ thick (aluminum pre-coated silica gel), silica gel column material (100-200 mesh) were obtained from Merck, India. Muller Hilton Agar (MHA) and Muller Hilton Broth (MHB) were obtained from Hi-Media, India. Resazurin was procured from Sisco Research Laboratories Pvt. Ltd. (SRL) - India. Tetracycline hydrochloride purchased from Sigma-Aldrich, India. Other chemicals and solvents were used from analytical grade without any further purification.

\section{Collection of plant material}

Apparently disease free healthy aerial parts of C. viscosa were collected from the botanical garden, University of Madras during the month of August - October (2014). Taxonomic identification of the plant was made by Prof. K. Murugesan, University of Madras, Guindy Campus and Chennai, India. The plant materials were washed twice with tap water to remove soil and dust particles and finally rinse with distilled water. The collected plants were shade dried and pulverized in a mechanical grinder and stored in a closed vessel for further use.

\section{Extraction and isolation}

The air dried, powdered aerial parts of C. viscosa $(100 \mathrm{~g})$ was extracted using a Soxhlet apparatus with $1 \mathrm{~L}$ of methanol at room temperature for $8 \mathrm{~h}$, the extraction procedure was repeated until the solvent become colorless. The obtained extract was condensed using a rotary evaporator (Lark Rotary Evaporator, Model RE 100-Pro). The $10 \mathrm{~g}$ of dark green methanolic residue was subjected to silica gel (100200 mesh) column chromatography and was eluted with the ratio of hexane and chloroform; chloroform and ethyl acetate; ethyl acetate and methanol (9:1 to 1:9 ratio). Totally, 96 fractions were collected and were pooled in to 8 major fractions based on the TLC profile such as Fr. I $(0.015 \mathrm{~g})$, Fr. II $(0.024 \mathrm{~g})$, Fr. III $(0.038 \mathrm{~g})$, Fr. IV $(0.026 \mathrm{~g})$, Fr. V (0.025 g), Fr. VI (0.017 g), Fr. VII (0.013 g) and Fr. VIII (0.015 g). The crystal compound was observed in the fraction III; it was purified further and characterized by the single crystal XRD, FTIR and ESI-MS.

\section{Single crystal X-ray crystallography}

In the present study, diffraction data for the crystals were collected using Bruker axs Kappa APEXII single crystal diffractometer ${ }^{23}$ available at the SAIF, IIT Madras, Chennai. Bruker axs Kappa APEXII has all the components needed to collect X-ray diffraction data from a single crystal. This is equipped with graphite monochromated $\mathrm{MoK}_{\alpha}$ radiation source ${ }^{23}$ and CCD detector. The unit cell parameters were determined from 36 frames $\left(0.5^{\circ}\right.$ phi-scan $)$ measured from three different crystallographic zones and using the method of difference vectors. Crystal structures were solved by direct methods with SHELXS-2014. ${ }^{24}$ The hydrogen atoms were located in the calculated positions and refined with a riding model. Molecular graphics were computed with PLATON. All non-hydrogen atoms were refined anisotropically and all hydrogen atoms were placed in geometrically calculated positions and refined as riding atoms with the relative isotropic parameters. The refined fractional atomic coordinates, bond lengths, bond angles and thermal parameters have been deposited.

\section{Density functional theory (DFT) calculations}

\section{Quantum chemical calculation}

The Allantoin molecule is optimized at B3LYP / 6-3 G (d) level using Gaussian) O3 Software. ${ }^{25}$ This B3LYP functional is already reported for its accurate results for most of the organic molecules and therefore the same is used here. ${ }^{26}$ The optimized geometers was subjected to frequency analysis to ensure that the geometry is corresponding to global minima. This was confirmed by obtaining all real frequencies. The atomic charges, dipole moment, HOMO, LUMO and electrostatic potential map of the molecule in the gaseous phase and in the active site have been analyzed. ${ }^{27,28}$

\section{FTIR spectral analysis}

FTIR spectrum of the purified compound was studied using $\mathrm{KBr}$ pellet and the absorbance was recorded in Perkin-Elmer spectrum one spectrometer at a scan range of $4000-400 \mathrm{~cm}^{-1}$.

\section{ESI-MS spectral analysis}

ESI-MS/MS analysis was performed mass spectrometer operated in the positive ion mode, and the optimized instrument conditions of MS were set as follows: spray voltage, $3.0 \mathrm{kV}$; capillary temperature, $250^{\circ} \mathrm{C}$; vaporizer temperature, $350^{\circ} \mathrm{C}$; cone voltage, $40.0 \mathrm{~V}$; sheath gas pressure, $40 \mathrm{psi}$; Aux gas pressure, $10 \mathrm{psi}$. Collision energies for the MS/ MS analysis ranged from $30-45 \mathrm{eV}$ in accordance with the mass of the precursor ion. Nitrogen (N2) was served as the cone and desolation gas and Helium $(\mathrm{He})$ was used as the collision gas. Mass spectrometry data were acquired full-scan mode for $\mathrm{m} / \mathrm{z}$ in the range from 200 to 1000 . All data acquisition and analysis was performed in the Thermo X caliber Chem. Station (Thermo Fisher Scientific, Waltham, MA, USA).

\section{Antibacterial activity}

The antibacterial activity of the isolated compound allantoin was tested against Bacillus subtilis, Staphylococcus aureus, Escherichia coli and Klebsiella pneumoniae determined by well diffusion method. The bacterial culture $\left(10^{7} / \mathrm{mL}\right)$ was swabbed uniformly on the Muller Hilton agar plate using a sterile cotton swab. The different concentration of allantoin $(10-40 \mu \mathrm{g} / \mathrm{mL})$ was added into each well and they were incubated at $37^{\circ} \mathrm{C}$ for $18 \mathrm{~h}$. After incubation, the appeared zone was measured. Standard antibiotic tetracycline was used as a positive control. The experiment was repeated twice.

\section{Determination of minimum inhibitory concentration (MIC)}

Minimum Inhibitory Concentration (MIC) of allantoin was determined against above mentioned pathogenic bacteria by broth dilution method. In brief, different concentrations of allantoin $(128,64,32,16,8,4,2,1$, $0.5,0.25 \mu \mathrm{g} / \mathrm{mL}$ ) was suspended in to $50 \mu \mathrm{L}$ of the MHB of medium and taken in to the 96 well plate followed by $20 \mu \mathrm{L}$ of bacterial suspension $(1 \times 10 \mathrm{CFU} / \mathrm{mL})$ were added to the each well and then it was incubated for $18 \mathrm{~h}$ at $37^{\circ} \mathrm{C}$. Tetracycline hydrochloride was taken as a positive control. After incubation $30 \mu \mathrm{L}$ of resazurin $(0.015 \%)$ was added to the each well and incubation period was extended another $3 \mathrm{~h}$. Based on the visible color changes the inhibitory concentration was calculated. The live cells exhibit the purple color and the dead cells exhibit the pink color. ${ }^{29}$

\section{Molecular docking}

Molecular docking analysis was performed on Centos 6 Linux workstation using Maestro. GLIDE - 6.0 searches were performed 
for understanding docking interactions between natural compound (allantoin) with DNA gyrase-II. All molecular modeling was carried out using OPLSAA (Optimized Potential Liquid Simulation for AllAtom) force field. ${ }^{30}$ Ligprep 2.3 modules ${ }^{31}$ were employed for natural compound (allantoin) preparation. ${ }^{32}$ The three-dimensional crystal structure of DNA Gyrase-II (PDB: 5L3J) was downloaded from the PDB (http://www.rcsb.org). Protein preparation wizard of Schrodinger was used for DNA gyrase preparation. No hydrogen atoms were minimized until the average root mean square deviation reached a default value of $0.3 \mathrm{~A}$. Sitemap 2.3 was used to understand binding site in the ligand-binding domain (LBD) of the DNA gyrase-II). ${ }^{31}$ Induced fit docking was performed to compounds binding modes and structural movements in the LBD region of DNA gyrase-II using Glide and Prime modules. The prepared proteins were loaded on the workstation and the grid values were calculated about $20 \AA$ to cover the entire active site amino acids. About 20 conformational images were created and analyzed for the best conformation pose based on the docking score and glide energy.

\section{Statistical analysis}

Analysis of variance (ANOVA) was carried out using SPSS program (version. 15). Means and standard deviation of three replicates were calculated. The results were considered significant at $p<0.05$.

\section{RESULTS AND DISCUSSION}

\section{Isolation of bioactive compound}

The isolated compound allantoin was carefully separated and was crystallized from fraction III by using solvent mixture at a ratio of hexane: chloroform: methanol (1.0:0.7:0.3) (SP. Figure 1 and SP. Figure 2 ). The compound was obtained by the salicylic acid biosynthesis ${ }^{10}$ proposed the presence of above compound that may be the intention of biotic and abiotic stress. They had also isolated a crystal compound nevirapine from the seeds of C. viscosa. The UV spectrum allantoin showed a strong absorption peak at $265 \mathrm{~nm}$. UV spectrum of allantoin showed a strong absorption peak at $265 \mathrm{~nm}$ and the absorbance was very close to the previous reports ${ }^{33}$ to determine the absolute structural configuration by single crystal XRD.

The crystal structure was solved by direct methods and was refined by full-matrix least-squares techniques (SHELXL-2014/7'). The structure was refined to the final R-factor 0.0213 (Figure 1 and Tables 1-4). It was initially refined with isotropic method and finally with anisotropic later constrained which HFIX command (SP. Tables 1-3). The title compound consists of dioxoimidazolidine ring attached to urea group, the imidazolidine is almost planar with maximum deviation of -0.0325 (13) $\AA$ for the carbon atom C3 (Figure 1). In the urea group is entire

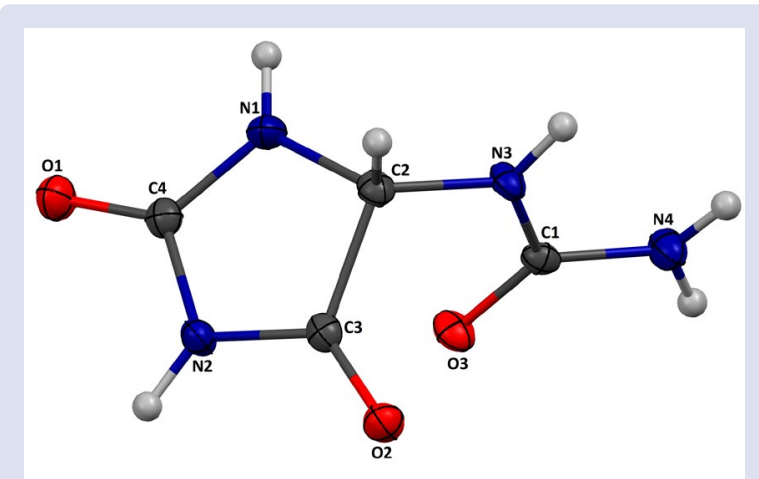

Figure 1: The ORTEP diagram of NFA27 with atom numbering scheme. Displacement ellipsoids are drawn at $30 \%$ probability level. The hydrogen atoms are present as small spheres of arbitrary radius.
Table 1: Crystal data for the compound NFA27.

\begin{tabular}{|c|c|}
\hline Parameters & NFA27 \\
\hline Empirical Formula & $\mathrm{C}_{4} \mathrm{H}_{6} \mathrm{~N}_{4} \mathrm{O}_{3}$ \\
\hline Formula weight $(\mathrm{g} / \mathrm{mol})$ & 158.13 \\
\hline Temperature (K) & $296(2)$ \\
\hline Wavelength $(\AA)$ & 0.71073 \\
\hline Crystal system & Monoclinic \\
\hline \multirow[t]{2}{*}{ Space group } & $\mathrm{P} 2_{1} / \mathrm{c}$ \\
\hline & $\mathrm{a}=8.0028(5)$ \\
\hline Unit cell dimensions & $\mathrm{b}=5.1439(3)$ \\
\hline $\mathrm{a}, \mathrm{b}$ and $\mathrm{c}(\AA)$ & $c=14.7608(8)$ \\
\hline \multirow[t]{2}{*}{$\alpha, \beta$ and $\gamma\left({ }^{\circ}\right)$} & $a=\gamma=90$ \\
\hline & $\beta=93.014(3)$ \\
\hline Volume $\left(\AA^{3}\right)$ & $V=606.80(6)$ \\
\hline $\mathrm{Z}$, calculated density $\left(\mathrm{Mg} / \mathrm{m}^{3}\right)$ & $4,1.731$ \\
\hline Absorption coefficient $\left(\mathrm{mm}^{-1}\right)$ & 0.149 \\
\hline $\mathrm{F}(000)$ & 328 \\
\hline Crystal size (mm) & $0.35 \times 0.25 \times 0.20$ \\
\hline \multirow[t]{2}{*}{$\theta$ range $\left(^{\circ}\right)$} & $2.55-24.98$ \\
\hline & $-09 \leq \mathrm{h} \leq 09$ \\
\hline \multirow[t]{2}{*}{ Index ranges } & $-06 \leq \mathrm{k} \leq 06$ \\
\hline & $-17 \leq 1 \leq 17$ \\
\hline \multirow{2}{*}{$\begin{array}{l}\text { Reflections collected / unique } \\
\text { reflections }\end{array}$} & 7714 / 1069 \\
\hline & {$\left[\mathrm{R}_{\mathrm{int}}=0.0210\right]$} \\
\hline Completeness of $\theta$ & $100.0 \%$ \\
\hline Refinement method & Full-matrix least squares on $\mathrm{F}^{2}$ \\
\hline Data/ restraints/ parameters & $1069 / 6 / 121$ \\
\hline Goodness of Fit on $\mathrm{F}^{2}$ & 1.114 \\
\hline \multirow{2}{*}{ Final $\mathrm{R}$ indices $[\mathrm{I}>2 \sigma(\mathrm{I})]$} & $\mathrm{R}=0.0262$ \\
\hline & $\mathrm{wR} 2=0.0678$ \\
\hline \multirow{2}{*}{ Final $\mathrm{R}$ indices (all data) } & $\mathrm{R}=0.0293$ \\
\hline & $\mathrm{wR} 2=0723$ \\
\hline $\begin{array}{l}\text { Largest difference peak } \\
\text { and hole }\left(\mathrm{e} . \AA^{-3}\right)\end{array}$ & 0.211 and \\
\hline
\end{tabular}

Table 2: Bond lengths (Å) involving non-hydrogen atoms of NFA27 with esd's in parentheses.

\begin{tabular}{cc}
\hline Atom & Length \\
\hline $\mathrm{C} 1-\mathrm{O} 3$ & $1.2405(16)$ \\
$\mathrm{C} 1-\mathrm{N} 4$ & $1.3291(17)$ \\
$\mathrm{C} 1-\mathrm{N} 3$ & $1.3562(17)$ \\
$\mathrm{C} 2-\mathrm{N} 3$ & $1.4226(16)$ \\
$\mathrm{C} 2-\mathrm{N} 1$ & $1.4530(16)$ \\
$\mathrm{C} 2-\mathrm{C} 3$ & $1.5345(17)$ \\
$\mathrm{C} 3-\mathrm{O} 2$ & $1.2113(16)$ \\
$\mathrm{C} 3-\mathrm{N} 2$ & $1.3495(17)$ \\
$\mathrm{C} 4-\mathrm{O} 1$ & $1.2202(16)$ \\
$\mathrm{C} 4-\mathrm{N} 1$ & $1.3344(17)$ \\
$\mathrm{C} 4-\mathrm{N} 2$ & $1.3895(17)$ \\
\hline
\end{tabular}

atoms lie in the same plane except $\mathrm{C} 1$ deviates from the rest of the atoms by -0.0099 (12) ̊. The orientation of the urea group (N3/N4/ $\mathrm{C} 1 / \mathrm{O} 3)$ is $(+)$ syn clinal to the allantoin ring $(\mathrm{N} 1 / \mathrm{N} 2 / \mathrm{C} 2 / \mathrm{C} 3 / \mathrm{C} 4)$ which is evident from the torsion angle $\mathrm{C} 3-\mathrm{C} 2-\mathrm{N} 3-\mathrm{C} 1=46.13(15)^{\circ}$. The bond lengths and bond angles are agreed well with each other for the reported crystal structure. ${ }^{18}$

In the crystal packing, the molecules are linked via $\mathrm{N}-\mathrm{H} \cdots \mathrm{O}$ intermolecular hydrogen bonds and it is stabilized by $\pi \cdots \pi$ 
Table 3: Bond angles ( $\left.{ }^{\circ}\right)$ involving non-hydrogen atoms of NFA27 with esd's in parentheses.

\begin{tabular}{cc}
\hline Atom & Angle \\
\hline O3-C1-N4 & $122.91(12)$ \\
O3-C1-N3 & $120.09(11)$ \\
N4-C1-N3 & $116.98(11)$ \\
N3-C2-N1 & $116.29(11)$ \\
N3-C2-C3 & $113.79(10)$ \\
N1-C2-C3 & $100.64(10)$ \\
O2-C3-N2 & $127.01(12)$ \\
O2-C3-C2 & $126.26(11)$ \\
N2-C3-C2 & $106.69(10)$ \\
O1-C4-N1 & $127.96(12)$ \\
O1-C4-N2 & $124.41(12)$ \\
N1-C4-N2 & $107.61(11)$ \\
C4-N1-C2 & $112.72(11)$ \\
C3-N2-C4 & $112.01(11)$ \\
C1-N3-C2 & $120.56(11)$ \\
\hline
\end{tabular}

Table 4: Torsion angles $\left(^{\circ}\right)$ for the non-hydrogen atoms of NFA27 with esd's in parentheses.

\begin{tabular}{cc}
\hline Atom & Angle \\
\hline $\mathrm{N} 3-\mathrm{C} 2-\mathrm{C} 3-\mathrm{O} 2$ & $51.42(17)$ \\
$\mathrm{N} 1-\mathrm{C} 2-\mathrm{C} 3-\mathrm{O} 2$ & $176.54(12)$ \\
$\mathrm{N} 3-\mathrm{C} 2-\mathrm{C} 3-\mathrm{N} 2$ & $-130.69(11)$ \\
$\mathrm{N} 1-\mathrm{C} 2-\mathrm{C} 3-\mathrm{N} 2$ & $-5.57(13)$ \\
$\mathrm{O} 1-\mathrm{C} 4-\mathrm{N} 1-\mathrm{C} 2$ & $176.99(13)$ \\
$\mathrm{N} 2-\mathrm{C} 4-\mathrm{N} 1-\mathrm{C} 2$ & $-1.71(15)$ \\
$\mathrm{N} 3-\mathrm{C} 2-\mathrm{N} 1-\mathrm{C} 4$ & $127.85(12)$ \\
$\mathrm{C} 3-\mathrm{C} 2-\mathrm{N} 1-\mathrm{C} 4$ & $4.44(14)$ \\
$\mathrm{O} 2-\mathrm{C} 3-\mathrm{N} 2-\mathrm{C} 4$ & $-177.01(12)$ \\
$\mathrm{C} 2-\mathrm{C} 3-\mathrm{N} 2-\mathrm{C} 4$ & $5.12(14)$ \\
$\mathrm{O} 1-\mathrm{C} 4-\mathrm{N} 2-\mathrm{C} 3$ & $178.88(13)$ \\
$\mathrm{N} 1-\mathrm{C} 4-\mathrm{N} 2-\mathrm{C} 3$ & $-2.36(15)$ \\
$\mathrm{O} 3-\mathrm{C} 1-\mathrm{N} 3-\mathrm{C} 2$ & $3.56(18)$ \\
$\mathrm{N} 4-\mathrm{C} 1-\mathrm{N} 3-\mathrm{C} 2$ & $-177.90(11)$ \\
$\mathrm{N} 1-\mathrm{C} 2-\mathrm{N} 3-\mathrm{C} 1$ & $-70.16(15)$ \\
$\mathrm{C} 3-\mathrm{C} 2-\mathrm{N} 3-\mathrm{C} 1$ & $46.12(16)$ \\
\hline
\end{tabular}

intermolecular interactions. The geometric details are given in Table 5. The aromatic nitrogen atom $\mathrm{N} 1$ acts as a donor via $\mathrm{H} 1 \mathrm{~A}$ atom to the oxygen atom $\mathrm{O} 3(2-x,-1 / 2+y, 1 / 2-z)$ of the urea group acts as acceptor and forms a one dimensional chain running parallel to [010] direction (Figure 2). In the crystal packing, the molecules are linked by $\mathrm{N} 2 \mathrm{~A}-\mathrm{H} 2 \mathrm{~A} \cdots \mathrm{O} 1(2-x, 1-y, 1-z)$ and $\mathrm{N} 3-\mathrm{H} 3 \mathrm{~A} \cdots \mathrm{O} 3(x,-1+y, z)$ intermolecular hydrogen bonding, together forming $R_{2}^{2}(8)$ and $R_{4}^{4}(26)$ graph-set ring motifs molecular sheet running parallel to $b c$ plane (Figure 3). In addition to that, N4A-H4A $\cdots \mathrm{O} 2(1-x, 1 / 2+y, 1 / 2-z)$ and $\mathrm{N} 4-\mathrm{H} 4 \mathrm{~B} \cdots \mathrm{O} 2(1-x,-1 / 2+y, 1 / 2-z)$ intermolecular hydrogen bonding, together forming $R_{2}^{2}(4)$ and $R_{2}^{4}(8)$ graph-set ring motifs molecular sheet running parallel to $b c$ plane (Figure 4 ), the crystal structure is characterized by $\mathrm{Cg} 1 \cdots \mathrm{Cg} 1$ intermolecular interaction between the imidazolidine ring and a symmetry-related imidazolidine ring of at $(2-x,-y, 1-z)$, with an interplanar spacing of 3.9612(8) $\AA$; ring-centroid separation is 3.262(1) $\AA$, with the slippage 2.247(1) $\AA$ where $\mathrm{Cg} 1$ is centroid of the imidazolidine ring $(\mathrm{N} 1 / \mathrm{N} 2 / \mathrm{C} 2 / \mathrm{C} 3 / \mathrm{C} 4)$. (Deposition number CCDC NO: 1540913; CRM: 0001000970775) (Figure 5). The Halothamnus auriculus is a halophilc plant that contains allantoin was isolated and reported.$^{34}$ Based on this study, it was concluded that the presence of crystalline compound might be due to the saline environment.

\section{Molecular modeling}

The optimized geometry is given in figure and its important geometrical parameters are collected and compared with X-ray crystal structure (Table 7). Results revealed that there is an excellent agreement with the DFT optimized geometry and the crystal structure. This validates the choice of the DFT method used for the present investigation. In order to identify the electrostatic nature of Allantoin molecular, electrostatic potential map was illustrated (SP. Figure 3).

To explore the electrostatic properties of the molecule, the Mulliken population analysis (MPA) ${ }^{35}$ was calculated and presented (Figure 6). The large differences are observed in nitrogen and oxygen atoms in the gaseous phase molecule and the molecule present in the active site of the protein. The dipole moment of the molecule is $6.86 \mathrm{D}$ in gas phase which is decreased when the molecule enters into the active site of the protein $(4.84 \mathrm{D})$ due to the effect of intermolecular interaction (Figure 7).

The high electronegative region that was found around the oxygen atoms of the molecule in the gaseous phase acted as a nucleophilic one. These atoms are the more reactive regions of the molecule which clearly confirmed from the active site molecule (Figure 8). The several global chemical reactivity descriptors are available such as electro negativity $(\chi)$, electrophilicity $(\varpi)$, and chemical hardness $(\eta)^{36}$ (Table 6). The calculated value of ionization potential, electronegativity and

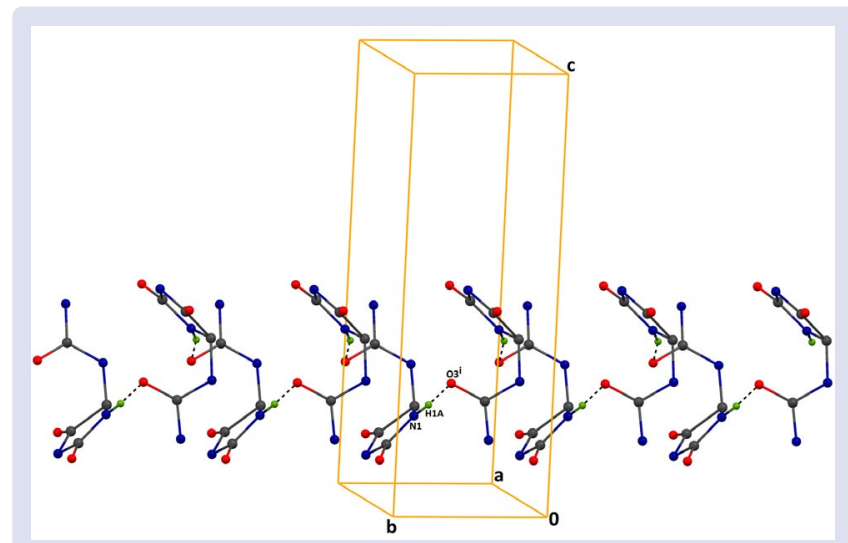

Figure 2: The crystal packing of the compound NFA27 viewed down c-axis. The dashed lines indicate $\mathrm{N}-\mathrm{H}$-... $\mathrm{O}$ intermolecular interactions, which are results in $C$ (6) chains running parallel to [010] direction. The hydrogen atoms not involved in the hydrogen bonding and nitrophenyl ring have been excluded for clarity. The Symmetry code: (i) $2-x,-1 / 2+y, 1 / 2-z$.

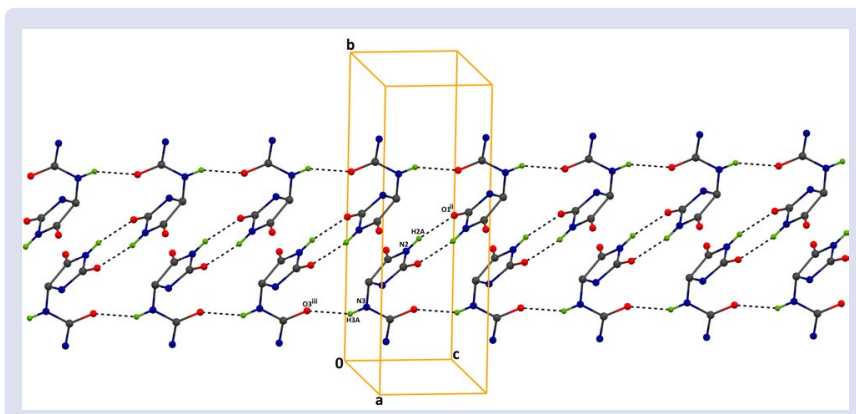

Figure 3: The crystal packing of the compound NFA27 viewed down $b$-axis. The dashed lines indicate $\mathrm{N}-\mathrm{H} \cdots \mathrm{O}$ intermolecular interactions, which are results in $R_{2}^{2}(8)$ and $R_{4}^{4}(26)$ alternate graph-set ring motifs. The hydrogen atoms not involved in the hydrogen bonding and nitrophenyl ring have been excluded for clarity. The Symmetry codes: (ii) $2-x, 1-y$, $1-z$; (iii) $x,-1+y$, 


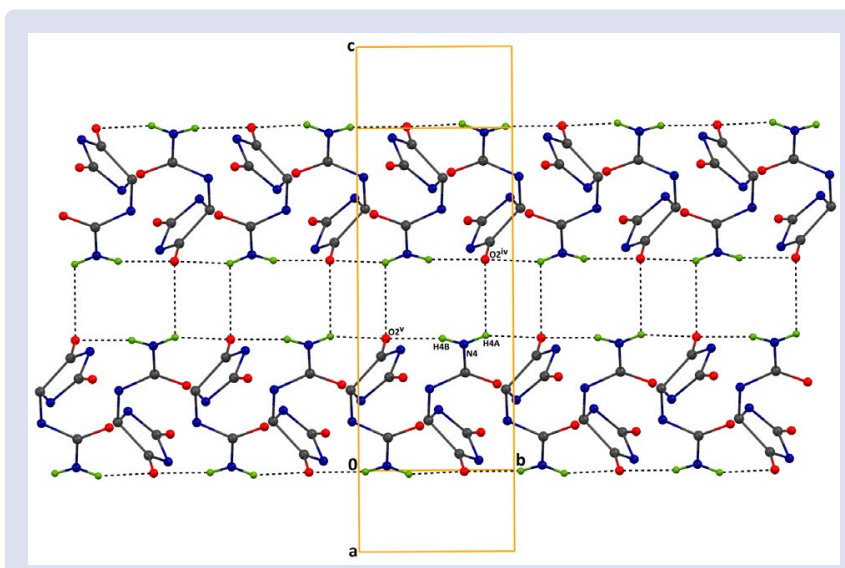

Figure 4: The crystal packing of the compound NFA27 viewed down c-axis. The dashed lines indicate $\mathrm{N}-\mathrm{H} \cdots \mathrm{O}$ intermolecular interactions, which are results in $R_{2}^{2}(4)$ and $R^{4}{ }_{2}(8)$ alternate graph-set ring motifs. The hydrogen atoms not involved in the hydrogen bonding and nitrophenyl ring have been excluded for clarity. The Symmetry codes: (iv) $1-x, 1 / 2+y, 1 / 2-z ;$ (v) $1-x,-1 / 2+y, 1 / 2-z$.

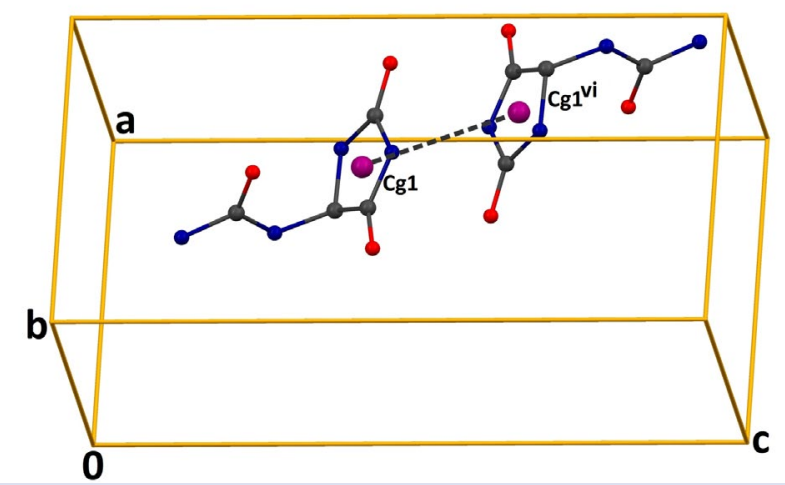

Figure 5: Part of crystal packing of compound NFA27 viewed down the $b$-axis. The dashed lines indicates $\mathrm{Cg} 1 \cdots \mathrm{Cg} 1^{\mathrm{v}}$ interactions, where $\mathrm{Cg} 1$ is centroid of the rings (N1/N2/C2/C3/C4). For the sake of clarity, $\mathrm{H}$ atoms bonded to $\mathrm{C}$ atoms not involved in the motif shown have been omitted. The symmetry code: (v) $2-x,-y, 1-z$.

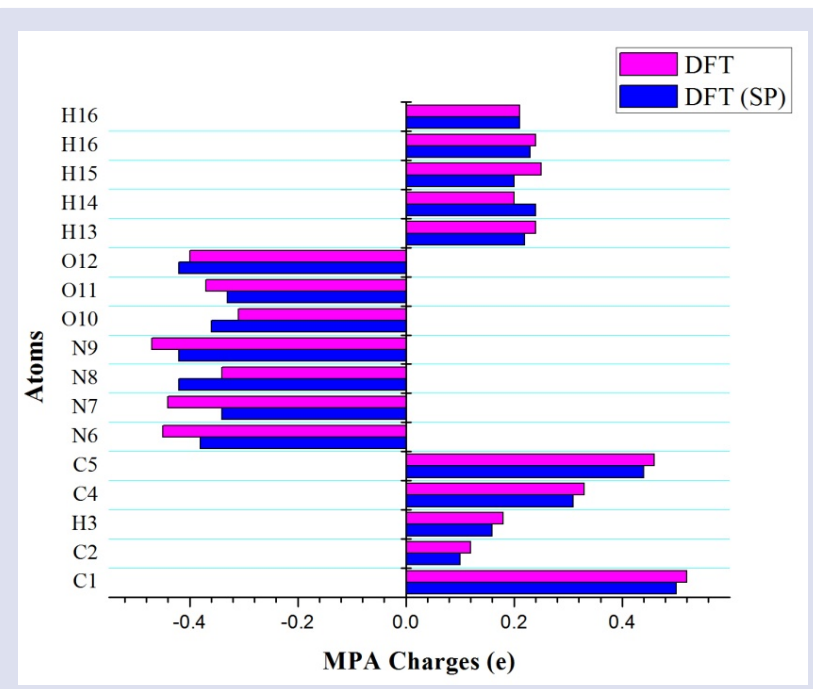

Figure 6: The MPA charge for gas phase and active site phase.

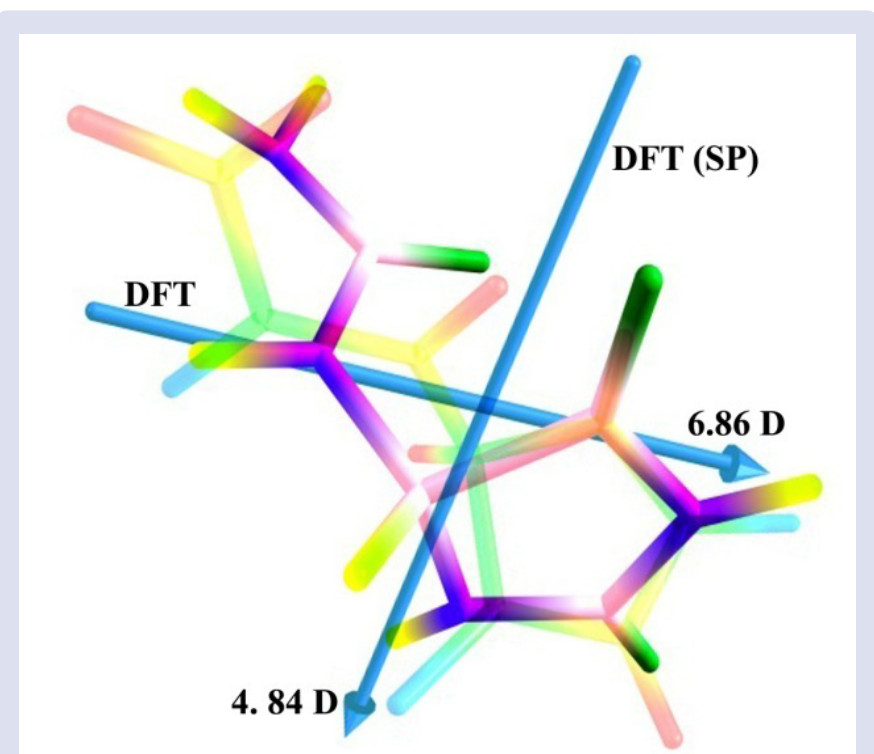

Figure 7: The orientation of dipole moment vectors of the molecule in gas phase and active site phase (the origin is center of mass of the molecule).

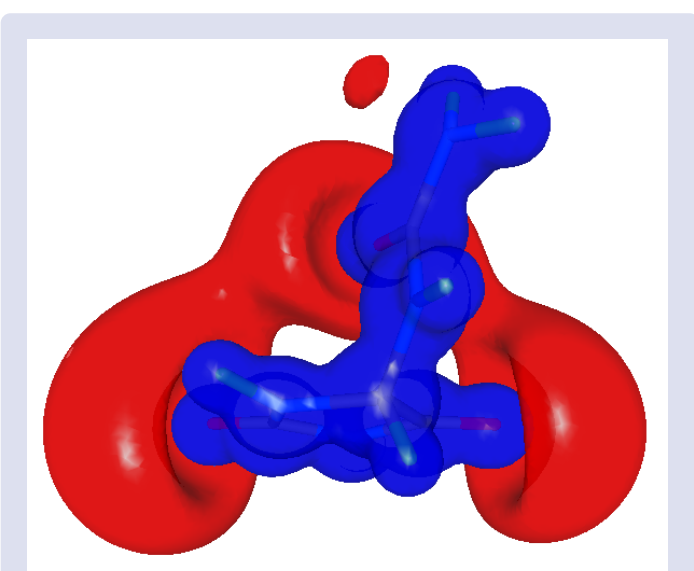

Figure 8: Electrostatic potential map of the molecule in gas phase and in the active site phase (Blue: positive potential; red: negative potential). The surface values are +0.5 and $-0.05 \mathrm{e}^{-1}$.

Table 5: Hydrogen bond geometry for NFA27 [Å and o].

\begin{tabular}{|c|c|c|c|c|}
\hline \multicolumn{4}{|c|}{ Distance (Å) } & \multirow{2}{*}{$\frac{\left.\text { Angle ( }{ }^{\circ}\right)}{D-H \cdots A}$} \\
\hline $\mathrm{D}-\mathrm{H} \cdots \mathrm{A}$ & $\mathrm{D}-\mathrm{H}$ & $H \cdots A$ & $D \cdots A$ & \\
\hline $\begin{array}{c}\mathrm{N} 1- \\
\mathrm{H} 1 \mathrm{~A} \cdots \mathrm{O}^{\mathrm{i}}\end{array}$ & 0.831 & $2.115(15)$ & $2.9181(15)$ & 162 \\
\hline $\begin{array}{c}\mathrm{N} 2- \\
\mathrm{H} 2 \mathrm{~A} \cdots 1^{\mathrm{ii}}\end{array}$ & 0.852 & $1.988(15)$ & $2.8257(15)$ & 167 \\
\hline $\begin{array}{c}\mathrm{N} 3- \\
\mathrm{H} 3 \mathrm{~A} \cdots \mathrm{O} 3^{\mathrm{iii}}\end{array}$ & 0.845 & $2.210(15)$ & $2.9116(14)$ & 140 \\
\hline $\begin{array}{c}\mathrm{N} 4- \\
\mathrm{H} 4 \mathrm{~A} \cdots \mathrm{O} 2^{\text {iv }}\end{array}$ & 0.838 & $2.217(16)$ & $3.0014(17)$ & 155 \\
\hline $\begin{array}{c}\mathrm{N} 4- \\
\mathrm{H} 4 \mathrm{~B} \cdots \mathrm{O} 2^{\mathrm{v}}\end{array}$ & 0.835 & $2.201(16)$ & $3.0188(17)$ & 166 \\
\hline
\end{tabular}

$\mathrm{Cg} 1$ is the centroid of the ring $(\mathrm{N} 1 / \mathrm{N} 2 / \mathrm{C} 2 / \mathrm{C} 3 / \mathrm{C} 4)$.

Symmetry codes: (i) $2-x,-1 / 2+y, 1 / 2-z$, (ii) $2-x, 1-y, 1-z$, (iii) $x,-1+y$, $z$, (iv) $1-\mathrm{x}, 1 / 2+\mathrm{y}, 1 / 2-\mathrm{z}$, (v) $1-\mathrm{x},-1 / 2+\mathrm{y}, 1 / 2-\mathrm{z}$ 


\section{Table 6: The calculated global reactivity properties of both molecules.}

\begin{tabular}{|c|c|}
\hline $\begin{array}{l}\text { Global Reactivity } \\
\text { Descriptors }\end{array}$ & $\begin{array}{c}\text { DFT-I } \\
\text { Energy }(\mathrm{eV})\end{array}$ \\
\hline Band Gap & -6.61 \\
\hline HOMO Energy & -7.18 \\
\hline LUMO Energy & -0.57 \\
\hline $\begin{array}{r}\text { Ionization Potential } \\
\mathrm{I}=-\mathrm{E}_{\text {номо }}\end{array}$ & 6.61 \\
\hline $\begin{array}{l}\text { Electron Affinity } \\
\qquad A=-E_{\text {LUMO }}\end{array}$ & 0.57 \\
\hline $\begin{array}{l}\text { Global Hardness } \\
\qquad \eta=(\mathrm{I}-\mathrm{A}) / 2\end{array}$ & 3.31 \\
\hline $\begin{array}{l}\text { Electronegativity } \\
\qquad X=(\mathrm{I}+\mathrm{A}) / 2\end{array}$ & 3.88 \\
\hline $\begin{array}{l}\text { Electrophilicity } \\
\qquad \omega=\mu^{2} / 2 \eta, \mu=-\chi\end{array}$ & 2.27 \\
\hline
\end{tabular}

Table 7: Comparison of selected bond parameters obtained from DFT optimization and X-ray crystallography (Bond Lengths are in $\AA$ and bond angles\& dihedral angles are in $\%$.

\begin{tabular}{|c|c|c|c|}
\hline S.No. & $\begin{array}{c}\text { Bond } \\
\text { Parameter }\end{array}$ & Crystal Structure & $6-31 \mathrm{~g}(\mathrm{~d})$ \\
\hline A & \multicolumn{3}{|c|}{ Bond Length } \\
\hline 1 & $\mathrm{~N}_{9}-\mathrm{C}_{1}$ & 1.32909 & 1.38672 \\
\hline 2 & $\mathrm{C}_{1}-\mathrm{N}_{8}$ & 1.35632 & 1.38499 \\
\hline 3 & $\mathrm{C}_{1}-\mathrm{O}_{12}$ & 1.24039 & 1.22207 \\
\hline 4 & $\mathrm{~N}_{8}-\mathrm{C}_{2}$ & 1.42262 & 1.43988 \\
\hline 5 & $\mathrm{C}_{2}-\mathrm{N}_{6}$ & 1.45290 & 1.45671 \\
\hline 6 & $\mathrm{~N}_{6}-\mathrm{C}_{5}$ & 1.33449 & 1.38187 \\
\hline 7 & $\mathrm{C}_{5}-\mathrm{O}_{10}$ & 1.22009 & 1.20990 \\
\hline B & \multicolumn{3}{|c|}{ Bond Angle } \\
\hline 1 & $\mathrm{~N}_{9}-\mathrm{C}_{1}-\mathrm{N}_{8}$ & 116.97 & 114.30617 \\
\hline 2 & $\mathrm{O}_{12}-\mathrm{C}_{1}-\mathrm{N}_{8}$ & 120.09 & 122.12949 \\
\hline 3 & $\mathrm{C}_{1}-\mathrm{N}_{8}-\mathrm{C}_{2}$ & 120.55 & 121.24885 \\
\hline 4 & $\mathrm{~N}_{8}-\mathrm{C}_{2}-\mathrm{C}_{4}$ & 113.79 & 112.85280 \\
\hline 5 & $\mathrm{~N}_{8}-\mathrm{C}_{2}-\mathrm{N}_{6}$ & 116.29 & 116.53846 \\
\hline $\mathrm{C}$ & \multicolumn{3}{|c|}{ Dihedral Angle } \\
\hline 1 & $\begin{array}{l}\mathrm{N}_{9}-\mathrm{C}_{1}- \\
\mathrm{N}_{8}-\mathrm{C}_{2}\end{array}$ & 177.91 & 178.76 \\
\hline 2 & $\begin{array}{l}\mathrm{C}_{1}-\mathrm{N}_{8}- \\
\mathrm{C}_{2}-\mathrm{N}_{6}\end{array}$ & 70.18 & 66.15367 \\
\hline
\end{tabular}

electron affinity of the molecule is $6.61,3.88$ and $0.57 \mathrm{eV}$ respectively. Electrophilicity index gives the information about the reactivity and toxicity of the molecule. The calculated electrophilic index is found to be low $(2.27 \mathrm{eV})$ and reflects low toxicity. Figure 9 shows the HOMO and LUMO of both forms of the molecule. The localization and delocalization of the atoms in the molecule were confirmed due to redistribution of charge in the active site.

\section{Characterization of allantoin}

The FTIR spectrum showed a strong and sharp vibration band peak at $3432,3336,3187,3051,1777,1650,1426,1391,1280 \mathrm{~cm}^{-1}$ which might be due to the presence of $-\mathrm{NH},-\mathrm{OH},=\mathrm{C}-\mathrm{H},-\mathrm{CH},-\mathrm{C}=\mathrm{O}, \mathrm{C}=\mathrm{C}$, - $\mathrm{CH}$ (bending),-CN (stretch),-C-O (stretch) groups. The IR spectrum of the titled compound showed strong absorption peak at 3432 and $1650 \mathrm{~cm}^{-1}$ for $\mathrm{OH}$ and $\mathrm{C}=\mathrm{O}$ respectively (Figure 10), the same was also corroborated by the findings. ${ }^{33}$ The mass spectrum of allantoin displayed a molecular weight at 158.13 which corresponds to the molecular formula $\mathrm{C}_{4} \mathrm{H}_{6} \mathrm{~N}_{4} \mathrm{O}_{3}$ (Figure 11).

\section{Antibacterial activity}

Increasing concentration of allantoin from $10-40 \mu \mathrm{g} / \mathrm{mL}$, increased the rate of inhibition of growth of $\mathrm{K}$. pneumoniae $(12 \pm 0.8 \mathrm{~mm})$,
E. coli $(12 \pm 1.4 \mathrm{~mm})$ (Figure 12 and Table 8$)$ of all the test bacteria including S. aureus $(10 \pm 1.1 \mathrm{~mm})$ and B. subtilis $(14 \pm 1.5 \mathrm{~mm})$; it was more pronounced in the former than in the latter, when compared to that of the standard tetracycline $(20 \mu \mathrm{g} / \mathrm{mL})$. The minimum inhibitory concentration (MIC) of allantion showed against both Gram positive and Gram negative bacteria even at the lower concentration; it is $4 \mu \mathrm{g} /$ $\mathrm{mL}$ for B. subtilis and $8 \mu \mathrm{g} / \mathrm{mL}$ for S. aureus, E. coli and $\mathrm{K}$. pneumoniae (Table 9). Özçelik and his co-workers observed that the standard Allantoin compound from Sigma showed the significant antibacterial activity in terms of MIC against B. subtilis $(8 \mu \mathrm{g} / \mathrm{mL})$, S. aureus $(16$ $\mu \mathrm{g} / \mathrm{mL}$ ), and $8 \mu \mathrm{g} / \mathrm{mL}$ for E. coli and $\mathrm{K}$. pneumonia. ${ }^{37}$ It was indicated that isolated Allantoin exhibit equal or better than standard in terms of antibacterial activity.

\section{Molecular docking simulation}

The optimized geometry was used for the molecular docking analysis. The molecular docking results are given in Figures 13,14 and Table 10. The DNA gyrase II (PDB: 5L3J) was used for the molecular docking analysis. The active site of AT bound proteins consists of ILE 78, ASN 46, GLU 50, GLY 75, VAL 120, ASP 73, VAL 167, VAL 43, ALA 47, VAL

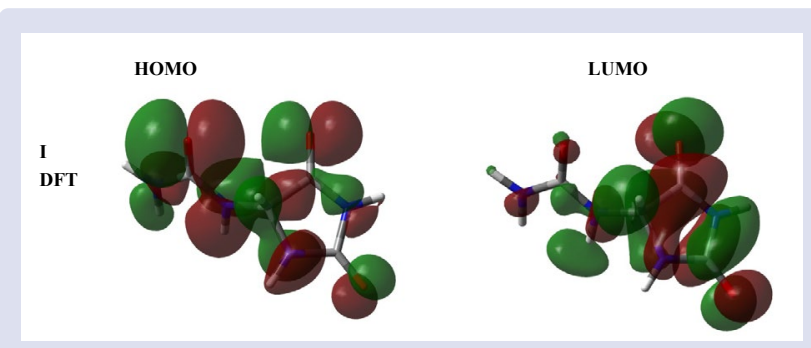

Figure 9: The HOMO and LUMO of the molecule was plotted at the isosurface value at $0.02 \mathrm{au}$.

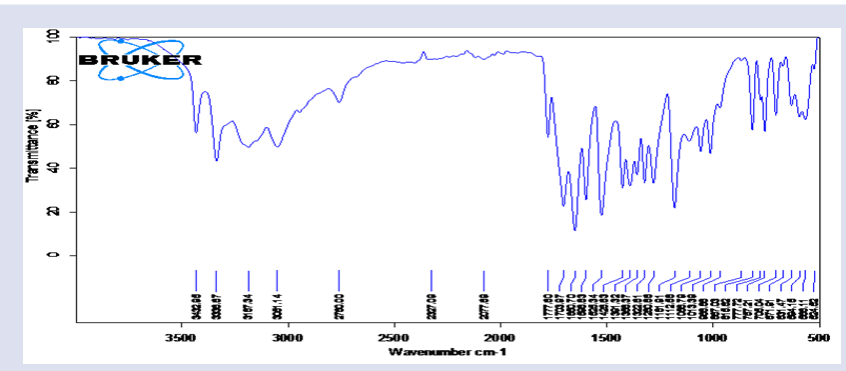

Figure 10: FT-IR spectrum of Allantoin.

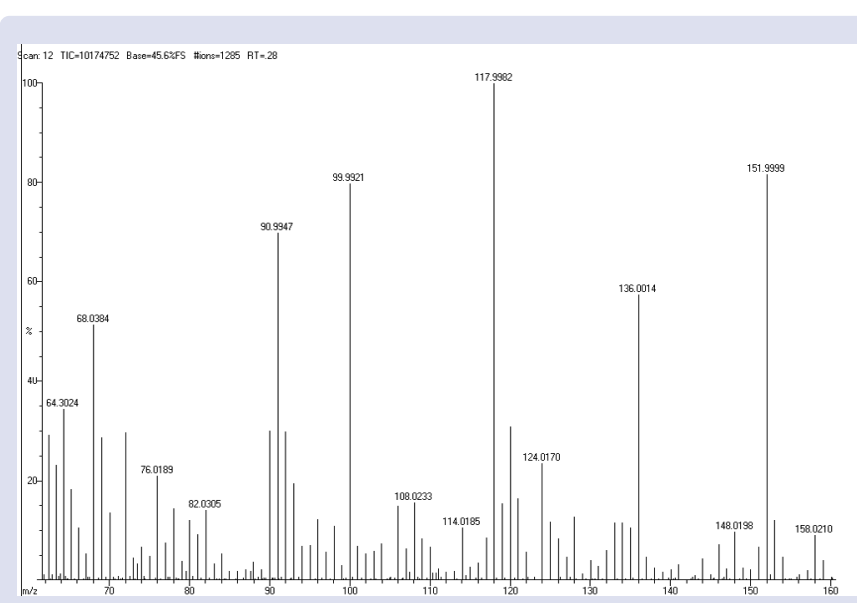

Figure 11: ESI-MS chromatogram of Allantoin. 
Herrera-Calderon, et al.: Effect of Sacha Inchi Oil (Plukenetia volubilis L.) on Genotoxicity in Mice (Mus musculus) and Subchronic Toxicity in Goldfish (Carassius auratus)

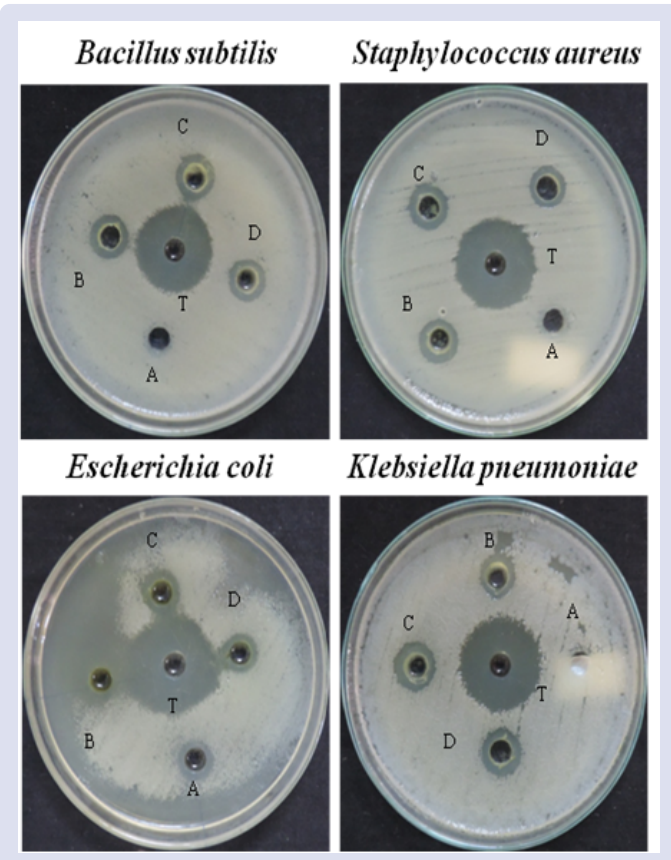

Figure 12: Antibacterial activity of Allantoin $A-10 \mu g /$ $\mathrm{mL}, \mathrm{B}-20 \mu \mathrm{g} / \mathrm{mL}, \quad C-30 \mu \mathrm{g} / \mathrm{mL}, \mathrm{D}-40 \mu \mathrm{g} / \mathrm{mL}, \mathrm{T}-$ Tetracycline $(20 \mu \mathrm{g} / \mathrm{mL})$ values represent the mean \pm SD of three replicates.

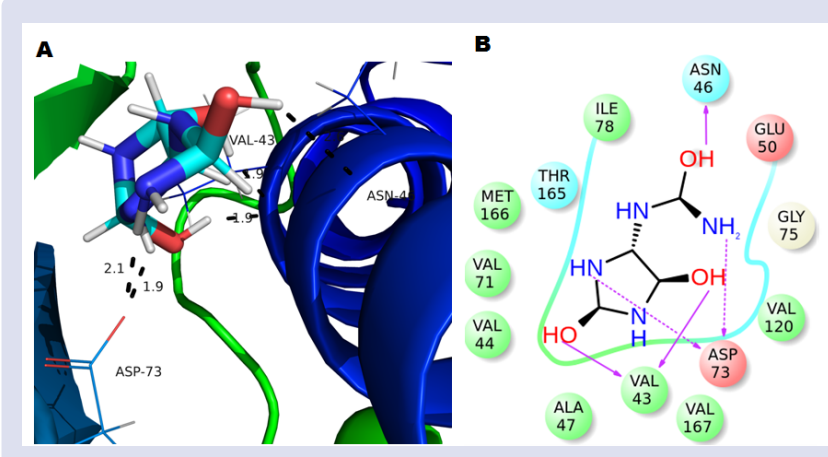

Figure 13: Natural compound (Allantoin) docked with bacterial drug target for DNA gyrase II (PDB ID: 5I3J) protein-ligand interactions A) 3D Pymol view B) 2D maestro view.

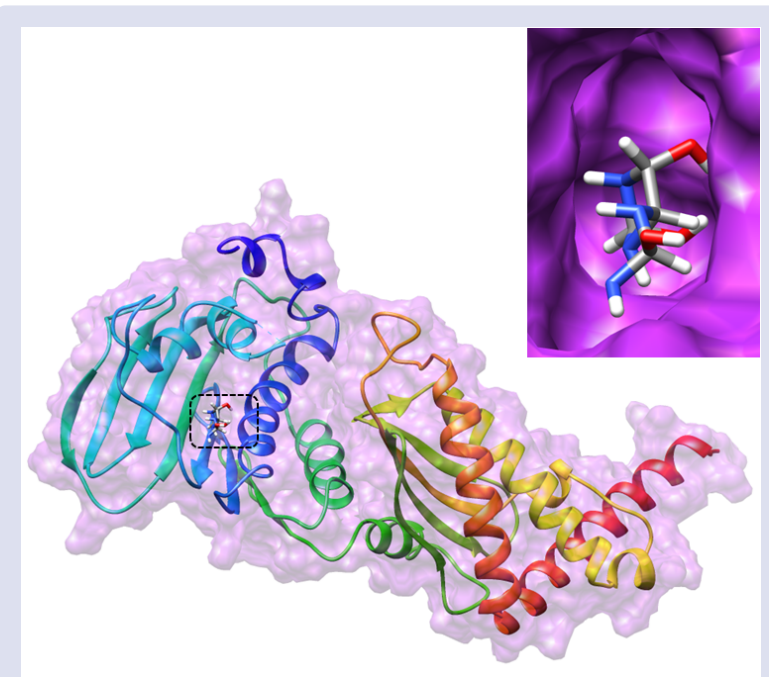

Figure 14: Cartoon and surface representation of compound (Allantoin) docked with DNA gyrase II at the active site pocket.
Table 8: Antibacterial activity of Allantoin (zone of inhibition in $\mathbf{m m}$ ).

\begin{tabular}{ccccc}
\hline $\begin{array}{c}\text { Allantoin } \\
(\mu \mathrm{g} / \mathrm{mL})\end{array}$ & $\begin{array}{c}\text { Bacillus } \\
\text { subtilis }\end{array}$ & $\begin{array}{c}\text { Staphylococcus } \\
\text { aureus }\end{array}$ & $\begin{array}{c}\text { Escherichia } \\
\text { coli }\end{array}$ & $\begin{array}{c}\text { Klebsiella } \\
\text { pnemoniae }\end{array}$ \\
\hline 10 & - & - & $7 \pm 0.4$ & - \\
20 & $7 \pm 0.8$ & $7 \pm 0.6$ & $8 \pm 1.2$ & $8 \pm 0.6$ \\
30 & $8 \pm 1.2$ & $8 \pm 0.8$ & $10 \pm 1.4$ & $11 \pm 1.6$ \\
40 & $10 \pm 1.5$ & $10 \pm 1.1$ & $12 \pm 1.4$ & $12 \pm 0.8$ \\
$\begin{array}{c}\text { Standard } \\
(\text { Tetracycline } \\
-20 \mu \mathrm{g} / \mathrm{mL})\end{array}$ & $18 \pm 1.4$ & $18 \pm 1.6$ & $20 \pm 1.2$ & $18 \pm 1.2$ \\
\hline
\end{tabular}

Table 9: Minimum inhibitory concentration of Allantoin.

\begin{tabular}{ccccc}
\hline \multirow{2}{*}{ Compound } & $\begin{array}{c}\text { Bacillus } \\
\text { subtilis }\end{array}$ & $\begin{array}{c}\text { Staphylococcus } \\
\text { aureus }\end{array}$ & $\begin{array}{c}\text { Escherichia } \\
\text { coli }\end{array}$ & $\begin{array}{c}\text { Klebsiella } \\
\text { pneumonia }\end{array}$ \\
\cline { 2 - 5 }$\left(\begin{array}{c}\text { Minimum inhibitory concentration }(\mu \mathrm{g} / \mathrm{mL}) \\
\hline \text { Allantoin }\end{array}\right.$ & 4 & 8 & 8 & 8 \\
Tetracycline & 0.25 & 0.25 & 0.5 & 0.5 \\
\hline
\end{tabular}

Table 10: Docking result for natural compound (Allantoin) against drug target of DNA gyrase II.

\begin{tabular}{cccc}
\hline Drug target & Compound & $\begin{array}{c}\text { Docking score } \\
\text { (Kcal/mole) }\end{array}$ & $\begin{array}{c}\text { Glide energy } \\
\text { (Kcal/mole) }\end{array}$ \\
\hline $\begin{array}{l}\text { DNA Gyrase-II } \\
\text { (PDB ID: 5L3J) }\end{array}$ & Allantoin & -4.78 & -25.18 \\
\hline
\end{tabular}

44, VAL 71, MET 166, and THR 165 . It is very interesting to note that this AT molecule tends to show three hydrogen bonding interactions with ASP 73, VAL 43 and ASN 46 with a distance of $2.1 \AA$. $2.0 \AA$ and 2.0 $\AA$ respectively. It revealed that this Allantoin has the ability to interact with DNA gyrase II and tend to show antibacterial activity.

\section{CONCLUSION}

Allantoin was isolated from C. viscosa and it was confirmed through single crystal XRD analysis and it showed hydrogen bond interactions with a supramolecular graph-set ring motif. DFT results revealed that there was an excellent agreement with X-ray crystal structure. Other important electronic properties such as atomic charges, dipole moment, DFT (HOMO-LUMO), electrostatic potential map of the molecule in gaseous phase have been explored. To the best of our knowledge, for the first time Allantoin isolated from C. viscosa have been shown to exhibit antibacterial activities against Gram-positive and Gram-negative bacteria. Molecular docking analysis has been done to throw light on the binding mode of Allantoin with DNA gyrase II. The preferential binding mode and nature was also studied.

\section{CONFLICTS OF INTEREST}

The authors declared no conflicts of interest.

\section{ACKNOWLEDGMENTS}

Authors of this study wish to thank the Director, CAS in Botany, University of Madras, Guindy Campus, Chennai for providing research laboratory and also thank UGC - UPE - Phase II for financial assistance and Instrumentation Facility, IIT Madras (SAIF) for spectral analysis.

\section{REFERENCES}

1. Newman DJ, Cragg G.M. Natural products as sources of new drugs from 1981 to 2014. Journal Natural Products. 2016;79:629-61.

2. Altemimi A, Lakhssassi N, Baharlouei A, Watson D, Lightfoot D. Phytochemicals: Extraction, isolation, and identification of bioactive compounds from plant extracts. Plants. 2017;6(4):42.

3. Minh N, Phat T, Dung T, ChiT. Phytochemistry letters two new flavonol glycosides from the leaves of Cleome viscosa L. Phytochemistry Letter. 2016;18:10-3.

4. Nguyen TP, Tran CL, Vuong CH, Hong T, Do T. Flavonoids with hepatoprotective activity from the leaves of Cleome viscosa L. Natural Product Research. 2017;31(22):2587-92. 
5. Asolkar OJCLV, Kakkar KK. Second supplement to glossary of indian medicinal plants with active principles: A-K (1965-1981). Council of Scientific \& Industrial Research (India). Publications \& Information Directorate. 1992;217.

6. Saroop S, Kaul V. Seed dimorphism in Cleome viscosa L. National Academy Science Letter. 2015

7. Devi BP, Boominathan R, Mandal SC. Evaluation of antipyretic potential of Cleome viscosa Linn. (Capparidaceae) extract in rats. Journal of Ethnopharmacology. 2003;87:11-3

8. Upadhyay RK. Plant latex: A natural source of pharmaceuticals and pesticides. International Journal Green Pharmacy. 2014;5:16-80.

9. Senthamilselvi MM, Kesavan D, Sulochana N. An anti-inflammatory and anti-microbial flavone glycoside from flowers of Cleome viscosa. Organic and Medicinal Chemistry Letters. 2012:2-19

10. Chatterjee A, Chattopadhyay SK, Tandon S, Kaur R, Gupta AK, Maulik PR, Kant $R$. Isolation of a unique dipyridodiazepinone metabolite nevirapine during large scale extraction of Cliv-92 from the seeds of Cleome viscosa. Industrial Crops \& Products. 2013;45:395-400

11. Erhoas LUK, Ouak DEA, Ingo ANC. Structural characterization of the major flavonoid glycosides from Arabidopsis thaliana Seeds. Journal Agricultural Food Chemistry. 2006; 54:6603-12.

12. Abdullah W, Elsayed WM, Abdelshafeek KA, Nazif NM, Singab NB. Chemical constituents and biological activities of Cleome genus: A brief review. International Journal Pharmacognosy and Phytochemistry Research. 2016:8:777-87.

13. Ailian GZ, Huayi Z, Qi QY. Chemical study on Rostellularia procumbens. Chinese Journal Appllied and Environmental Biology. 2006:12(2):170-5.

14. Wei Y, Xie Q, Fisher D, Sutherland IA. Separation of patuletin-3-O-glucoside, astragalin, quercetin, kaempferol and isorhamnetin from Flaveria bidentis (L.) Kuntze by elution-pump-out high-performance counter-current chromatography. Journal Chromatography A. 2011;1218:6206-11.

15. Wang $X$, Liu B, Chen C, Wang J, Lee S. Four new fluorenone alkaloids and one new dihydroaza fluoranthene alkaloid from Caulophyllum robustum Maxim. Fitoterapia. 2011;82:793-7.

16. Anirban Jana, Suparna Mandal Biswas. Lactam nonanic acid, a new substance from Cleome viscosa with allelopathic and antimicrobial properties. Brief communication - Indian Academy of Sciences. 2011;36:27-35

17. Lee M, Lee N, Jung D, Lee J, Seo C, Lee H, Kim J, Shin H. Protective effects of allantoin against ovalbumin (OVA) induced lung in flammation in a murine model of asthma. International Journal of Immunopharmacology. 2010;10:474-80.

18. Parveen M, Azaz S, Zafar A, Ahmad F, Silva MR, Sidonio P, et al. Structure elucidation, DNA binding specificity and antiproliferative proficiency of isolated compounds from Garcinia nervosa. Journal of Photochemistry \& Photobiology B. 2017.

19. Lj V, Nikoli VD, Arsi IA, Stanojevi LP, Najman SJ, Stojanovi S, Mladenovi II. Comparative study of the biological activity of allantoin and aqueous extract of the comfrey root. Phytotheraphy Research. 2015;1122:1117-22.

20. Hsu S. Green tea and the skin. Journal of the American Academy of Dermatology. 2005:1049-59.
21. Shestopalov AV, Shkurat TP, Mikashinovich ZI, Kryzhanovskaya IO, Bogacheva MA, Lomteva SV. Biological functions of allantoin. Izvestiya Akademii Nauk Seriya Biologicheskaya. 2006;33:437-40.

22. Ahmed M, El Mubarak S, Lamari FN, Kontoyannis C. Simultaneous determination of allantoin and glycolic acid in snail mucus and cosmetic creams with high performance liquidchromatography and ultraviolet detection. Journal of Chromatography A. 2013;1322:49-53.

23. G. Sheldrick. 2008. XPREP Version 2008/2. Bruker AXS Inc. Madison.

24. Sheldrick GM. Crystal structure refinement with SHELXL. Acta Crystallographica. 2015:C71:3-8.

25. Frisch JAPMJ, Trucks GW, Schlegel HB, Scuseria GE, Robb MA, Cheeseman JR, et al. Gaussian 03, Revision D.1, Gaussian, Inc: Wallingford. CT,. (n.d.). 2009.

26. Solomon RV, Veerapandian P, Angeline Vedha S, Venuvanalingam P. Tuning nonlinear optical and optoelectronic properties of vinyl coupled triazene chromophores: A density functional theory and time-dependent density functional theory investigation. The Journal of Physical Chemistry A 2012;116:4667-77.

27. Dennington R, Keith $T$, and Millam J. Gauss View, Version 5. Semichem Inc. Shawnee Mission. Scientific researcher an academic publisher. Semichem Inc. 2009.

28. Stash Al, Tsirelson VG. Developing WinXPRO: a software for determination of the multipole-model-based properties of crystals C. Journal of Applied Crystallography. 2014:2086-9.

29. Sivaranjan K, Vanitha $P$, Sathiyaseelan $A$, Kalaichelvan PT, Sathuvan $M$ Rengasamy $R$, et al. Insights into the catalytic reduction of organic dyes and antibacterial activity of graphene oxide supported mono and bimetallic nanocomposites. New Journal Chemistry. 2017;41:4348-59.

30. Friesner RA, Banks JL, Murphy RB, Halgren TA, Klicic JJ, Mainz DT, et al. Glide : A New approach for rapid, accurate docking and scoring 1 method and assessment of docking accuracy. Journal of Medicinal Chemistry. 2004:173949.

31. Protein Prepwizard-Schrodinger. (2014-2).

32. Halgren T. New Method for fast and accurate binding-site identification and analysis. Chemical Biology \& Drug Design. 2007;146-8.

33. Alam MJ, Ahmad S. Molecular and biomolecular spectroscopy FTIR, FT-Raman UV - Visible spectra and quantum chemical calculations of allantoin molecule and its hydrogen bonded dimers. Spectrochimica Acta A. 2015;136:961-78.

34. Khakwani S, Riaz N, Ahmad S, Jabbar A. Phytochemical studies on Halothamnus auriculus. Journal of Global Biosciences. 2015;4:1563-70.

35. Politzer P, Murray JS, Peralta-inga Z. Molecular surface electrostatic potentials in relation to noncovalent interactions in biological systems. International Journal of Quantum Chemistry. 2001;85:676-84.

36. Vijayaraj R, Subramanian V, Chattaraj PK. Comparison of global reactivity descriptors calculated using various density functionals: A gsar perspective. Journal of Chemical Theory and Computation. 2009;5(10):2744-53.

37. Özçelik B, Kartal M, Orhan I, Özçelik B, Kartal M, Orhan I. Cytotoxicity, antiviral and antimicrobial activities of alkaloids, flavonoids, and phenolic acids. Pharmaceutical Biology. 2011;49(4):396-402

\section{GRAPHICAL ABSTRACT}

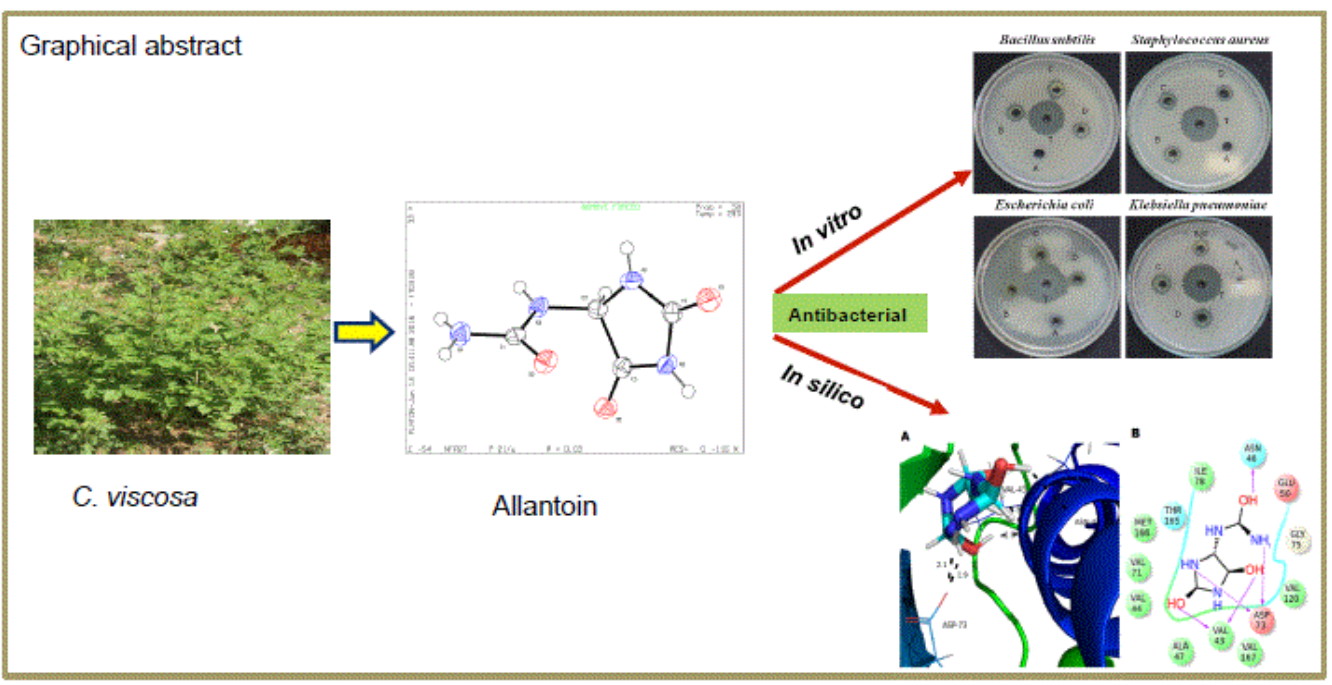




\section{ABOUT AUTHORS}

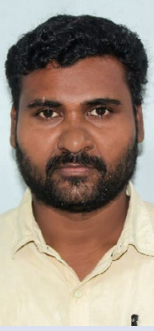

Dr. G. Lakshmanan worked as Junior Scientist of Central Research Laboratory at Meenakshi Academy of Higher Education (MAHER), Chennai and India. He has mainly focused on "isolation, identification and purification of bioactive compounds from medicinal plants with biological activities". Drug discovery is one of the creating of biological resources. The products are synthesis of drug as well as understanding of target molecule and bioactive molecules. They are also included in drug discovery of chemistry. From this, drug discovery is an interdisciplinary research that requires for understanding of biology and chemistry. He has published 8 papers in reputed journals 11 Books Published.

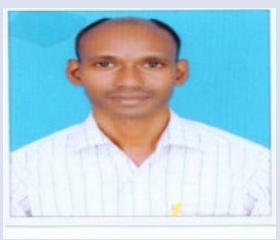

Dr. C. Sivaraj is working as a Research Analyst in ARMATS BIOTEK Training and Research Institute, Guindy, Chennai and India - 600 032. His Research interest is Isolation of Anticancer Drug from Natural Sources and he has experience in Phytochemistry and Natural products.

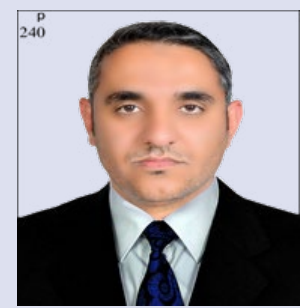

Dr. Ammar Altemimi worked as Lecturer (2009 - present) in Department of foodscience and Biotechnology, University of Basrah, Iraq. He is now the chair of food science department, college of Agriculture, University of Basrah. Developing academic programs, monitor students educational progress, train and motivate other non-teaching staff; manage career counseling and other student service. He has published more than 20 papers in reputed journals such as Ultrsonic Sonochemistry Journal and Molecules Journal; and he has been serving as an editorial board member and reviewers of repute Journals.

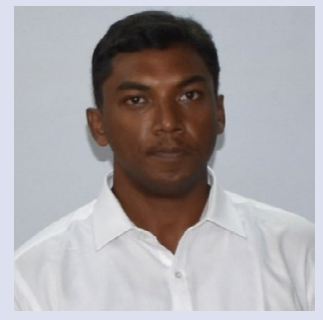

Dr. S. Gopinath worked as Assistant Professor (Un-Aided Management Staff), Department of Physics, RKM Vivekananda College (Autonomous), Mylapore CHENNAI - 600004 . He has experience in the field of X-Ray Crystallography, Single Crystal X-ray Diffraction, Crystal Growth, Crystal Structure Determination, Structures with disorders. He has published 10 papers in reputed journals.

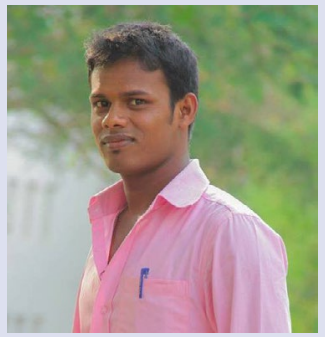

Dr. K. Saravanan has obtained his Ph. D in the Department of Physics, Periyar University, Salem under the guidance of Prof. P. Kumaradhas. He has obtained B. Sc (Physics) degree from the Department of Physics, Presidency College, Chennai in 2011 and M. Sc (Biophysics) from the CAS in Crystallography and Biophysics, University of Madras, Chennai in 2013. His research interests include X-ray crystallography, Molecular docking, Molecular dynamics simulation and OM/MM based Charge density analysis. Current interest of his research is to identify potential inhibitors for the AChE, BACE1 and GSK3 $\beta$ enzymes which are responsible for Alzheimer disease.

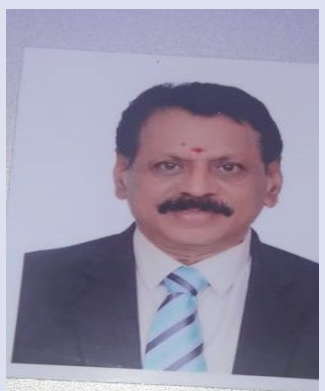

Prof K. Murugesan Professor in Centre for Advanced Studies in Botany, University of Madras, Chennai and has held many academic and administrative posts besides being awarded many awards and honours. The prominent among them was the prestigious UGC - BSR Distinguished Scientist Award in the year 2010 and he was also accorded UGC - BSR Faculty Fellow in the year 2014. Besides this, he has many research publications and accolades to his credit. He has experience in the area of Plant Molecular Biology, Plant Bio-Technology and Cancer Biology. He has published more than 103 papers in reputed journals 16 Books Published 7 Chapters and Guided 27 candidates for their Ph.D.s. 


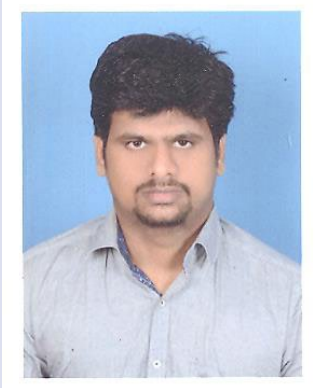

D. Anantha Krishnan is pursuing a PhD in Structural Biology and Structural Bioinformatics at the Department of Centre of Advanced Study in Crystallography and Biophysics, University of Madras, Chennai, India. He received award of Senior Research Fellowship ICMR (India) in 2018. His core research domains include 3D-QSAR, Pharmacophore modeling, Molecular dynamics simulation and Systems biology. He is currently working on protein-protein interaction network analysis of autophagy and its implications in cancer and neurodegenerative diseases.

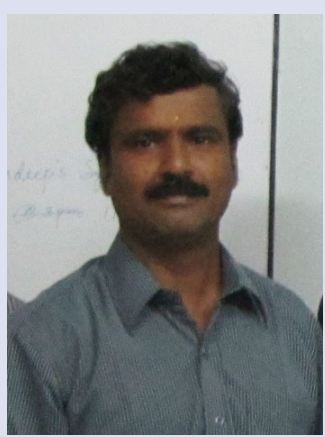

Dr. K. Gunasekaran Assistant professor at Centre of Advanced Study in Crystallography and Biophysics, University of Madras; 11 years of teaching and research experience in the areas of X-ray crystallography and spectroscopy studies, Bioinformatics and Structure based drug design; 5 years of experience in the isolation and characterization of lectins from plant proteins; Guided 12 candidates for their Ph.D.s and published 98 research papers so far with more than 70 international publications. He is awarded UGC-CSIR NET; JRF \& Lectureship, 1992.

Cite this article: Lakshmanan G, Sivaraj C, Ammarn A, Anantha Krishnan D, Gopinath S, Saravanan K, et al. Isolation and Structural Elucidation of Allantoin a Bioactive Compound from Cleome viscosa L.: A Combined Experimental and Computational Investigation. Pharmacog J. 2019;11(6)Suppl:1391-1400. 